\title{
UV Irradiation as a Disinfection Method to Reduce Covid-19 Cross-Contamination in Dentistry: A Scoping Review
}

\author{
Gabriela Malateaux ${ }^{1 *}$, Rodrigo Salazar Gamarra ${ }^{2}$ and Luciano Lauria Dib $^{3}$ \\ ${ }^{1}$ MSc Student of the Post-graduation of the Paulista University (UNIP), São Paulo, SP, Brazil \\ ${ }^{2}$ PhD Student of the Post-graduation of the Paulista University (UNIP), São Paulo, SP, Brazil \\ ${ }^{3}$ Professor of the Post-graduation of the Paulista University (UNIP), São Paulo, SP, Brazil
}

*Corresponding author: Gabriela Malateaux, Rua Dona Avelina, 350-Vila Mariana, São

Received Date: May 27, 2020

Paulo, SP, Brazil.

\begin{abstract}
The new coronavirus (COVID-19) quickly became a pandemic. Its transmission occurs mainly by direct contact, but its indirect transmission cannot be neglected. The dental office becomes a place of a high risk of contamination, mainly through aerosols and particles decanted on the surface. Concern about biosafety has become imminent and essential supplies of personal protection have become scarce. Several methods of disinfecting protective materials, the environment, and surfaces are being studied to reduce cross-infection, such as ultraviolet (UV) light. Our objective was to conduct a review of the recent literature in order to elucidate the use of UV technology in disinfecting environments and surfaces to reduce crosscontamination of COVID-19 in the health area, and how it can be used in the dental area. The PubMed database was used, and the articles were selected according to their relevance between 2018 and 2020. It is concluded that decontamination in environments and surfaces is effective, while the use of UV in PPE seems to be possible but deserves attention. It is suggested to carry out further studies aimed at disinfection by UV light in the dental area so that it can be used safely and effectively.
\end{abstract}

Keywords : UV disinfection; UV disinfection and COVID-19; UV disinfection; Dentistry

\section{Introduction}

The beginning of the epidemic disease caused by the new coronavirus (COVID-19) was notified in December 2019. On January 30, 2020, World Health Organization (WHO) announced that this would be an emergency outbreak of public health and international interest. In early march, COVID-19 was detected in many countries and was therefore compatible with a pandemic [1-8].

The transmission of the new coronavirus occurs mainly through direct means, through coughing, sneezing, and inhalation of droplets present in the air, however, it can also occur through indirect means, through contact with contaminated mucous membranes, hands, objects, and surfaces [2-4, 9-15]. Therefore, the dental office is a place of a high risk of contamination, mainly through aerosols suspended in the air and decanted on surfaces [16]. As the pandemic progressed, concerns about the biosafety of health professionals and prevention of cross-infection increased, as did concerns about the worldwide shortage of critical personal protective supplies and protective equipment (PPE) [1,2,17-19]. The PPE most used by these professionals are gloves, long-sleeved aprons, glasses, surgical masks, visors, and respiratory masks of the type $n 95$ or PFF2 [1, 2, 17, 20-23], all of which are manufactured for single use [1].

Due to the increase in the number of cases and the difficulty in maintaining basic supplies of individual protection for health professionals, it was started to think about ways to reuse them. 
Most conventional sterilization technologies used in hospitals or dental offices cannot effectively reprocess PPE due to the nature of their modalities, which will damage them [1]. Given that coronavirus and other respiratory viruses are significantly less resistant to sterilization modalities, the use of high to moderate level disinfection is sufficient to meet the needs of PPE reprocessing, and ultraviolet $\mathrm{C}$ (UV-C) irradiation can be effective for this purpose $[1,24,25]$.

UV-C is proven to reduce bacterial and viral contamination in several health services, addressing the disinfection of air, water, and surfaces [26-29]. In this sense, the question is: will this technology help us to control infections at the dental office level? Can we use it to disinfect objects and PPE? This article aims to review the literature in order to elucidate the use of technologies based on UV-C for disinfecting surfaces and environments in different fields in the health area, and how these can be inserted in the routine of the dental office. , aiming to decrease the risk of cross-infection by COVID-19.

\section{Materials and Methods}

\section{Identify the research question}

Can ultraviolet (UV) light be used to disinfect contaminated environments and surfaces in the health area? How can we insert it into the routine within the dental office, aiming at reducing the risk of cross-infection by COVID-19?

\section{Data collection and identification}

Systematic searches were performed through the identification of descriptors and the use of the Boolean operator (AND). The following descriptors were used: UV disinfection, UV disinfection and COVID-19, UV disinfection and dentistry

1) The year of publications was defined, from 2018 to 2020, as well as the English language.

2) The research was carried out in April 2020, in the PubMed database.

3) The articles were selected after a thorough analysis of their abstracts.

\section{Selection of studies}

The studies first selected were those that contained subjects related to UV disinfection in health care fields, their abstracts were carefully read and in a second selection, only research related to the dental field or that could be referred to dentistry were chosen.

\section{Results}

14 studies were selected for analysis and discussion.

\section{(Figure 1).}

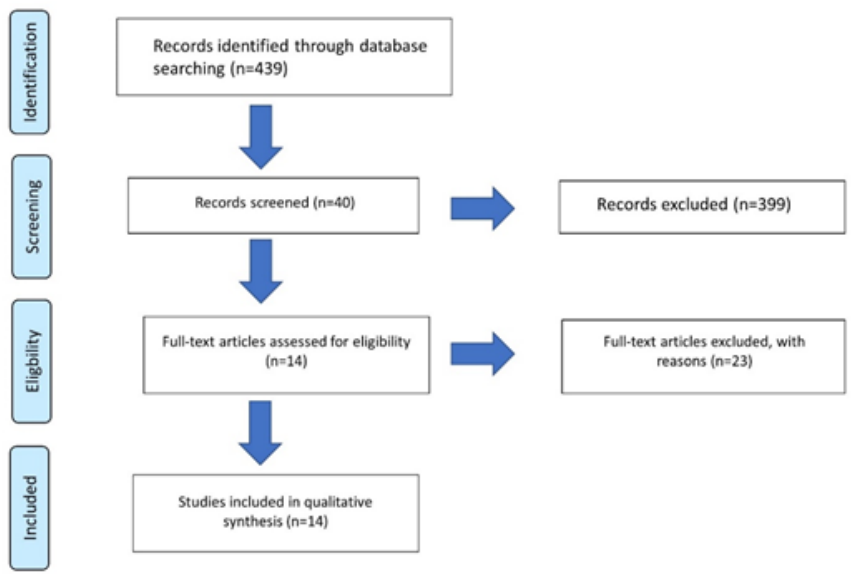

Figure 1: Flowchart selection of articles.

\section{Discussion}

With the pandemic imminent, the scarcity of PPE materials and knowing that the new coronavirus can survive at least 3 days in a variety of materials (stainless steel, plastic, glass, etc.) [15, 26, 30, 31], several disinfection methods have been studied to decrease the risk of cross-contamination, including ultraviolet radiation. Ultraviolet radiation is a fraction of the electromagnetic spectrum that covers wavelengths below visible light. It is sub-divided into
UV-A (ultraviolet A) with wavelengths from 320 to $400 \mathrm{~nm}$ which is capable of causing changes in the skin causing aging; UV-B (ultraviolet B), with wavelengths from 280 to $320 \mathrm{~nm}$, which causes genetic mutations and can lead to skin cancer [32]; and UV-C (ultraviolet C) with wavelengths from 200 to $280 \mathrm{~nm}$ [32-34], which is the most harmful band, being the germicidal band, interacting directly with the genetic material of the microorganisms, inactivating them and interrupting their contagion cycle [32]. 
UV irradiation has been proposed as a method of terminal disinfection in a variety of applications such as air, water, and contaminated surfaces [26, 28, 29, 35-38], and it can also be generated $\sin$ different ways, the most traditional being the mercury gas lamp. Currently, new technologies are being used without the presence of mercury, such as xenon pulsed light (200 to $300 \mathrm{~nm}$ ) that is emitted in a short duration, high pulse intensity, requiring a shorter exposure time [1, 36, 39], and the technology based on LED (light emitting diode), which proposes the use of smaller equipment, with fast start up time and equal efficiency, however, with low energy load [40]. Regardless of the source of ultraviolet light, the most effective wavelength is $254 \mathrm{~nm}[36,39$ 45]. After UV irradiation, the DNA sequence of microorganisms can form pyrimidine dimers, which can interfere with DNA duplication, as well as lead to the destruction of nucleic acids and make viruses non-infectious [44].

According to a systematic review carried out in 2015, surfaces such as stethoscopes, cell phones, pagers, computers, tablets, and other objects present in outpatient and hospital environments are susceptible to contamination by bacteria and viruses. The use of germicidal wipes and the use of other chemical disinfection methods, mainly for use in electronic equipment, are discouraged by some manufacturers, for example, the user manual for Apple devices recommends that "soft, lint-free cloth should be used to clean the device". However, just a cloth is not enough to disinfect a contaminated surface [46]. A recent study evaluated whether regular cleaning with any germicidal towel or UV-C irradiation decreases microbiological levels compared to irregular cleaning. They concluded that both methods of disinfection are effective and that UV-C irradiation can be a great alternative to objects and surfaces that cannot be disinfected with chemical substances [46].

Napolitani et al. (2020) [41], investigated the effectiveness of a 'wearable in aprons' device that emits ultraviolet $\mathrm{C}$ light by LED in the disinfection of stethoscopes, and through preliminary studies discovered a similar device that proved to be effective. In 10 stethoscopes analyzed, the average number of CFU was 9.5 after treatment and 75.9 without treatment. In another study, 3 auscultations were performed on a volunteer. The first was performed as a control, while the other two tested the disinfection capacity of UV-C LEDs. A total of 104 CFU were found at the baseline, while 12 and 15 CFU were found after 2 independent tests. Another study was conducted in a private clinic, the sample not treated with UV-C showed 132.2 CFU while the treated sample showed contamination of $6.9 \mathrm{CFU}$ in stethoscopes [41].

A study proposed at a teaching hospital in China evaluated infection control in animal laboratories and the disinfectant effects of portable pulsed xenon (PX-UV) ultraviolet device. Samples were taken from the survey surface, door handles, scales, trolley handles, and air in the barrier system. A manual cleaning using cloths moistened with $0.5 \%$ peracetic acid on surfaces and spraying $1 \%$ peracetic acid in the air was done in a pre-PX-UV way in one group and another not. The device was set at a wavelength of $100 \mathrm{mn}$ to $400 \mathrm{~nm}$, a frequency of $3 \mathrm{~Hz}$, and working duration of 6 min. PX-UV disinfection significantly reduced the count of residual microorganisms in the group with previous manual cleaning; From 10 to 1 . Without manual cleaning, the PX-UV was also effective, with an average count dropping from 6 to zero. In the air it reduced the microorganism count from 6 to zero, too. They concluded that PX-UV is an effective tool for disinfecting pathogens in various environments [47].

The disinfection of ambulances is extremely critical and necessary to prevent cross-contamination. Song et al. (2020) [36] carried out a study to test whether a UV irradiation device would be able to reduce pathogens in this environment, with the prerogative that manual chemical disinfection is dangerous and prone to error; based on a study that says persistent contamination is still found in the patient's compartment even after manual cleaning with chlorine and hydrogen peroxide. This device, manufactured for 'closed air' and that can be used in the presence of people, being powered and operated automatically when the ambulance is started, was evaluated by measuring the level of bioaerosol before and after UV disinfection and obtained as a result of more than $90 \%$ disinfection after UV light [36].

In 2020, Szeto et al. [39] conducted a study where several suspensions of bacteria and viruses were added to the filter paperand subjected to illumination by UV-C light generated by low-pressure Hg vapor lamps. The extension of the pathogen and inactivation at different times of illumination was investigated through a series of experiments. In the best-tested situation, bacterial inactivation can be achieved in less than or equal to 10 minutes of treatment with UV-C, except for mycobacterium tuberculosis, which required about 30 min of treatment. For viruses, especially influenza viruses, 20 minutes of treatment were necessary, indicating that UV-C light is an effective approach against different microorganisms 39, a fact that goes in accordance with what Kim and Kang say in 2018 They claim that microorganisms that contain DNA do not have a repair system, being more vulnerable to UV-C irradiation than microorganisms that have RNA [42].

Bringing UV-C to the dental reality, Binns et al. [48] (2020) investigated the effect of $254 \mathrm{~nm}$ ultraviolet light in the disinfection of candida albicans in polymethylmethacrylate prosthesis bases. They found that exposure to UV-C light of 300s inhibited the survival of $\mathrm{C}$. albicans close to the level of $3.8 \%$ sodium perborate, however, perborate can cause roughness on the surface of the prosthesis, so ultraviolet irradiation is an effective alternative for this purpose [48]. Regarding the use of UV-C light in the disinfection of PPE, the literature is still very scarce. The last study carried out on masks proved to be effective and did not affect the penetration of the aerosol into the masks' filters and did not change their appearance. However, attention must be paid to the exposure time and further studies must be carried out to prove this purpose [1]. 
The use of touchless disinfection reduces the risk of human errors arising from traditional manual cleaning. UV disinfection is less effective in shaded areas because it receives a lower dose of UV compared to directly exposed areas $[26,43]$. Kitagawa et al. [43] (2020) carried out a study that visually showed that areas that were protected against PX-UV light remained with the growth of microorganisms. Therefore, if not handled well, UV light is also prone to human error. They concluded that in order to obtain adequate disinfection of a hospital environment it is necessary that it is tidy, the use of an ideal device for the environment to be disinfected and its correct handling must be used [43]. Dexter et al. [26] (2020) clarify that the best form of disinfection is the manual one followed by UV-C light, and as the whole process takes around 1 hour, depending on the number of employees engaged to do so, and if the UV-C light machine needs circulate or not, it is advisable, if possible, to interchange service rooms [26].

With regard to contaminated water, most studies evaluate disinfection in pathogens that cause gastrointestinal infections. Rockey et al. [49] (2020) found that UV-C irradiation was effective in inactivating the HuNov virus. Another study evaluated disinfection in water containing rotavirus and Tulane virus, where they obtained an interesting result: due to different genomes and capsids, they were the target of UV irradiation in different ways. UV irradiation decreased the binding of the Talune virus to its receptor on the host and mutated its genome. Regarding rotavirus, UV irradiation allowed the interaction between viruses and hosts but prevented the replication of its genome. UV-C irradiation is also effective for this purpose [49].

In contrast to everything that has been said previously, Ciofi Silva et al. [50] (2019) evaluated the presence of residual NovGII particles in floors and air particles, following various floor decontamination procedures. Two types of flooring (vinyl and granite) were contaminated with human feces positive for the virus. Two decontamination protocols were implemented: cleaning followed by disinfection with $1 \%$ sodium hypochlorite and cleaning followed by disinfection using a manual UV-C light device for 30 min. Samples were collected from the floor and from the air, as the virus in question can be aerosolized while cleaning the floor and its particles can be inhaled, swallowed, or set under surfaces. The disinfection protocol with $1 \%$ sodium hypochlorite after cleaning proved to be more effective. In the air, there was no statistically significant difference between the types of flooring [50].

\section{Conclusion}

There are not many studies in the literature related to the use of ultraviolet $\mathrm{C}$ light in dentistry. However, through studies in other areas, we can predict its use in it. Regarding the disinfection of surfaces and objects liable to contamination, UV-C light (254nm) proved to be effective, mainly associated with previous manual cleaning. This disinfection scheme can be used in clinical rooms between patients, in furniture, cell phones, computers, for example.
The elimination of fungi in dentures with UV-C light proved to be a plausible alternative, however other microorganisms should be tested. In PPE's, its use is possible through proper exposure and handling; Further studies should be carried out in this regard regarding the use of UV-C light in different scenarios and conditions.

Disinfection of contaminated air has also proved to be effective, but studies are lacking showing its effectiveness in aerosols generated by dental procedures, which are highly contaminated. With the COVID-19 pandemic and the growing concern about biosafety and cross-infection, it is suggested that further studies aimed at disinfection by ultraviolet light in the dental area be suggested, so that it can be used safely and effectively.

\section{Acknowledgment}

This study was financed in part by the "Coordenação de Aperfeiçoamento de Pessoal de Nível Superior- Brazil (CAPES)"Finance Code 88887.488989/2020-00

\section{Conflicts of Interest}

The authors declare no conflicts of interest.

\section{References}

1. Rowan NJ, Laffey JG (2020) Challenges and solutions for addressing critical shortage of supply chain for personal and protective equipment (PPE) arising from Coronavirus disease (COVID19) pandemic -Case study from the Republic of Ireland. Sci Total Environ 725.

2. Barra A, Chefe De Gabinete T, Schuck K, Mendes H, Antônio D, et al (2020) Orientações Para Serviços De Saúde: Medidas De Prevenção E Controle Que Devem Ser Adotadas Durante A Assistência Aos Casos Suspeitos Ou Confirmados De Infecção Pelo Novo Coronavírus (SarsCov-2).

3. Peng X, Xu X, Li Y, Cheng L, Zhou X, et al. (2020) Transmission routes of 2019-nCoV and controls in dental practice. Int J Oral Sci 12(1): 1-9.

4. Meng L, Hua F, Bian Z (2020) Coronavirus Disease 2019 (COVID-19): Emerging and Future Challenges for Dental and Oral Medicine. J Dent Res 99(5): 481-487.

5. De Albuquerque NLS, Pedrosa NL (2016) The names of the COVID-19 em Cinco países com transmissão comunitária and doença. Relatórios and Acad Ciências 469(3): 319-323.

6. Liu YC, Kuo RL, Shih SR (2020) COVID-19: the First Documented Coronavirus Pandemic in History. Biomed Journal.

7. Croda JHR, Garcia LP (2020) Resposta imediata da Vigilância em Saúde à epidemia da COVID-19. Epidemiol e Serv saude Rev do Sist Unico Saude do Bras 29(1): e2020002.

8. De Oliveira W (2020) Como o Brasil pode deter a COVID-19. Epidemiol Serv Saúde 29(2)

9. Peeri NC, Shrestha N, Rahman MS, Zaki R, Tan Z, et al. (2020) The SARS, MERS and novel coronavirus (COVID-19) epidemics, the newest and biggest global health threats: what lessons have we learned? Int J Epidemiol 1-10.

10. Caruso AA, Del Prete A, Lazzarino AI, Capaldi R, Grumetto L (2020) May hydrogen peroxide reduce the hospitalization rate and complications of SARS-CoV-2 infection? Infect Control Hosp Epidemiol 1-5.

11. Khader Y, Al Nsour M, Al-Batayneh OB, Saadeh R, Bashier H, et al. (2020) Dentists' Awareness, Perception, and Attitude Regarding COVID-19 and Infection Control: Cross-Sectional Study Among Jordanian Dentists. JMIR Public Heal Surveill 6(2): e18798. 
12. Franco JB, Camargo AR de, Perres MPS de M (2020) Cuidados Odontológicos and era do COVID-19: recomendações para procedimentos odontológicos e profissionais 74(1): 18-21.

13. Wuhan D (2020) Doença pelo Coronavírus 2019 (COVID-19): Uma A bordazem P reventiva para Odontologia 10-6.

14. Lo Giudice R (2020) The Severe Acute Respiratory Syndrome Coronavirus-2 (SARS CoV-2) in Dentistry. Management of Biological Risk in Dental Practice. Int J Environ Res Public Health 17(9): 3067.

15. Sonja A Rasmussen, John C Smulian, John A Lednicky, Tony S Wen, Denise J Jamieson (2020) Sustainability of Coronavirus on different surfaces. Ann Oncol.

16. Odeh ND, Babkair H, Abu-Hammad S, Borzangy S, Abu-Hammad A, et al. (2020) COVID-19: Present and Future Challenges for Dental Practice. Int J Environ Res Public Heal 17(9): E3151.

17. Neves J (2020) Profissionais de saúde precisam estar protegidos, pois fazem parte da infraestrutura de resposta a esta epidemia [Internet] Escola Politécnica de Saúde Joaquim Venâncio - FIOCRUZ.

18. Falta De Epi Preocupa Oms (2020) Associação Médica Brasileira.

19. Gragnani J (2020) "Cuidamos dos outros, mas ninguém cuida de nós": as enfermeiras expostas ao coronavírus por falta de equipamentos. BBC News.

20. Personal protective equipment. World Health Organization

21. Tomé G, Bernardes SR, Guandalini S, Guimarães MCV (2020) Manual De Boas Práticas Em Biossegurança Para Ambientes Odontológicos.

22. Ricci WA (2020) Manual Odontológico de Biossegurança COVID 19. Soc Bras Periodontol.

23. COVID-19 C de OA de enfrentamento ao (2020) Recomendações AMIB para atendimento odontológico COVID- 19. Assoc Med Intensiva Bras (11).

24. Cadnum JL, Li D, Redmond SN, John AR, Pearlmutter B, et al. (2020) Effectiveness of Ultraviolet-C Light and a High-Level Disinfection Cabinet for Decontamination of N95 Respirators. Pathog Immun 5(1): 52-67.

25. Liao L, Xiao W, Zhao M, Yu X, Wang H, et al. (2020) Can N95 respirators be reused after disinfection? And for how many times? ACS Nano.

26. Dexter F, Parra MC, Brown JR, Loftus RW (2020) Perioperative COVID-19 Defense: An Evidence-Based Approach for Optimization of Infection Control and Operating Room Management. Anesth Analg

27. Xu R, Gong L, Wang H, Zhang G (2020) Disinfection Effect of Short-wave Ultraviolet Radiation(UV-C) on ASFV in Water. J Infect 80(6): 671-693.

28. Rudhart SA, Günther F, Dapper L, Thangavelu K, Gehrt F, et al. (2020) UV light-based decontamination : an effective and fast way for disinfection of endoscopes in otorhinolaryngology? Eur Arch Otorhinolaryngol

29. Ultravioleta. In vivo-Fundação Oswaldo Cruz (2013)

30. Ren SY, Wang WB, Hao YG, Zhang HR, Wang ZC, et al. (2020) Stability and infectivity of coronaviruses in inanimate environments. World J Clin Cases 8(8): 1391-1399.

31. Fiorillo L, Cervino G, Matarese M, D’Amico C, Surace G, et al. (2020) COVID-19 Surface Persistence: A Recent Data Summary and Its Importance for Medical and Dental Settings. Int J Environ Res Public Health 17(9): E3132.

32. USP delivers squeegees with ultraviolet radiation to hospital for decontamination (2020)

33. Amaral D, Antonio M (2020) The use of ionizing UVGI radiation to protect against the Corona Virus. 1950(2): 8-10.
34. Imanichi, Filho, Moraes (2017) Biological effects of ultraviolet radiation and its role in skin carcinogenesis: a review. Electronic Review of Fac Ceres 6(1): 2317-1367.

35. Prasanth T, Mandlik VB, Kumar S, Jha AK, Kosala M (2010) Evaluation of aerosol and water contamination and control of cross infection in dental clinics. Med J Armed Forces India 66(1): 37-40.

36. Song L, Li W, He J, Li L, Li T, et al. (2020) Development of a Pulsed Xenon Ultraviolet Disinfection Device for Real-Time Air Disinfection in Ambulances. J Healthc Eng.

37. Tseng CC, Li CS (2007) Inactivation of viruses on surfaces by ultraviolet germicidal irradiation. J Occup Environ Hyg 4(6): 400-405.

38. Gonçalves ALD (2020). Researchers create UV LEDs capable of eliminating the coronavirus.

39. Szeto W, Yam WC, Huang H, Leung DYC (2020) The efficacy of vacuumultraviolet light disinfection of some common environmental pathogens. BMC Infect Dis 20(1).

40. Betzalel Y, Gerchman Y, Cohen-Yaniv V, Mamane H (2020) Multiwell plates for obtaining a rapid microbial dose-response curve in UV-LED systems. Journal of Photochemistry and Photobiology B: Biology 207

41. Napolitani M, Bezzini D, Moirano F, Bedogni C, Messina G (2020) Methods of disinfecting stethoscopes: Systematic review. Int J Environ Res Public Health 17(6): 1856.

42. Kim DK, Kang DH (2018) UVC LED Irradiation Effectively Inactivates Aerosolized Viruses, Bacteria, and Fungi in a Chamber-Type Air Disinfection System.

43. Kitagawa H, Tadera K, Hara T, Kashiyama S, Mori M, et al. (2020) Efficacy of pulsed xenon ultraviolet disinfection of multidrug-resistant bacteria and Clostridioides difficile spores. Infect Dis Heal.

44. Bergman MS, Viscusi DJ, Zhuang Z, Palmiero AJ, Powell JB, et al. (2012) Impact of multiple consecutive donnings on filtering facepiece respirator fit. Am J Infect Control 40(4): 375-380.

45. Alexandre FA, Faria, José de Assis Fonseca Cardoso CF (2008) Evaluation of ultraviolet radiation in the sterilization of plastic packaging. Ciênc agrotec 32(5): 1524-1530.

46. Allen EM, McTague MF, Bay CP, Esposito JG, von Keudell A, et al. (2020) The effectiveness of germicidal wipes and ultraviolet irradiation in reducing bacterial loads on electronic tablet devices used to obtain patient information in orthopaedic clinics Evaluation of tablet cleaning methods. J Hosp Infect.

47. Li JJ, Wang SN, Qiao JJ, Chen LH, Li Y, et al. (2020) Portable pulsed xenon ultraviolet light disinfection in a teaching hospital animal laboratory in China. J Photochem Photobiol B Biol 207

48. Binns R, Li W, Wu CD, Campbell S, Knoernschild K, et al. (2020) Effect of Ultraviolet Radiation on Candida albicans Biofilm on Poly (methylmethacrylate) Resin. Journal of Prosthodontics.

49. Rockey N, Young S, Kohn T, Pecson B, Wobus CE, et al. (2020) UV Disinfection of Human Norovirus: Evaluating Infectivity Using a GenomeWide PCR-Based Approach. Environ Sci Technol 54(5): 2851-2858.

50. Ciofi-Silva CL, Bruna CQM, Carmona RCC, Almeida AGCS, Santos FCP, et al. (2019) Norovirus recovery from floors and air after various decontamination protocols. J Hosp Infect 103(3): 328-334 